\title{
Power Shifts in the Saudi-Iranian Strategic Competition
}

\author{
Aidan Parkes ${ }^{1}$
}

\begin{abstract}
The tensions between The Islamic Republic of Iran (IRI) and the Kingdom of Saudi Arabia (KSA) have afflicted the Gulf, and the broader Middle East region pervasively since the 1979 Islamic Revolution of Iran. The most theoretically illuminating feature of this conflict is that rather than isolated and regional, it develops parallel to global shifts in power. This article analyses the ascensions of two Islamic powers, and how their ascensions have aligned, commensurate to trends in global polarity. While religious incongruence underpins an aversion that is predicated on sectarianism, structural implications of polarity remain pervasive, and omnipresent in explaining the way states interact with one another. Polarity theory has been applied to the Middle East in the regional sense. However, the literature pertaining to how global polarity inflects on the SaudiIranian contest is understudied. It is this space in scholarship this paper seeks to address.
\end{abstract}

Keywords: Polarity, Security, Strategic Studies, Iran, Saudi Arabia

\section{Cambios de poder en la competencia estratégica entre Arabia Saudita e Irán}

Las tensiones entre la República Islámica de Irán (RII) y el Reino de Arabia Saudita (RAS) han afectado al Golfo, y a la región más amplia de Medio Oriente desde la Revolución Islámica de Irán en 1979. La característica más teóricamente ilustradora de este conflicto es que, en lugar de ser aislado y regional, se desarrolla paralelamente a los cambios globales en el poder. Este artículo analiza el crecimiento de dos poderes islámicos, y cómo estos mismos se han alineado de acuerdo con las tendencias en la polaridad global. Si bien la incongruencia religiosa sustenta una aversión que se basa en el sectarismo, las implicaciones estructurales de la polaridad siguen

1 Aidan Parkes (Aidan.Parkes@anu.edu.au) is a Doctoral Candidate at the Centre for Arab \& Islamic Studies (CAIS), Australian National University (ANU). 
siendo generalizadas y omnipresentes en la explicación de la forma en que los estados interactúan entre sí. La teoría de la polaridad se ha aplicado al Medio Oriente en el sentido regional. Sin embargo, la literatura relacionada con la inflexión de la polaridad global en la competencia entre Arabia Saudita e Irán está poco estudiada. Es este espacio de la investigación al que este trabajo pretende contribuir.

Palabras clave: polaridad, seguridad, estudios estratégicos, Irán, Arabia Saudita

\section{沙特-伊朗战略竞争中的权力转变}

\section{摘要}

伊朗伊斯兰共和国（IRI）和沙特阿拉伯王国（KSA）之间的 紧张关系自1979年伊朗伊斯兰革命发起之后便使波斯湾和大 中东地区倍感压力。从理论上讲, 这种冲突最明显的特征则 是, 它和全球权力转变的发展并行, 而不是被隔离作为区域 事务 (看待)。本文分析了两大伊斯兰势力的崛起, 以及这 种权力提升如何发展并顺应全球格局极化趋势。尽管宗教矛 盾加强了宗派主义中所预示的相互反感，但权力极化的结构 性意义依旧无处不在, 它能解释各国相互影响的方式。本文 从区域的角度将极化理论应用于中东。然而, 有关全球权力 极化如何影响沙特-伊朗之间的竞争的学术文献并不充足。本 文试图填补这一研究空缺。

关键词：极化，安全，战略研究，伊朗，沙特阿拉伯

\section{Introduction}

7 his article explores the contributing factors that explain the protracted animosity between the Islamic Republic of Iran (IRI) and the Kingdom of 1 Saudi Arabia (KSA). The scope of this paper will focus primarily on post1979 Iran and the foundation of the Saud Dynasty in 1744. The objective of this paper is to understand the modern zeitgeist of an ever-complicating and multiplex relationship. The year 1979 is also widely considered the inception of a modern 
"Shiite Crescent," which will be discussed further. ${ }^{2}$ The 1979 Islamic Revolution in Iran crystallized modern state Shiism in an irreducibly adversarial position to the Wahhabi-predicated Saudi Regime. Hence, although the modern Saudi-Iranian quandary has deep historical roots, its modern roots, within the scope of this study are traced to the Iranian Revolution of 1979 and Wahhabism's institutional marriage to the House of Saud in 1744. Within this focus, this article applies geopolitical theories in analyzing the applicability of global polarity to specific cases. Despite the theoretical applicability of polarity theory to the Saudi-Iranian rivalry, most of the literature views the rivalry simply as a subset of the broader SunniShia debate, alliances, and great power patrons.

Polarity theory has been applied to the Middle East in the regional sense (Kausch 2015). However, the literature pertaining to how global polarity inflects on the Saudi-Iranian contest is understudied. It is this space in Middle Eastern scholarship, this paper seeks to harmonize. With regard to a theoretical framework, this paper applies international relations theory to the regional contestation between Iran and Saudi Arabia. Global polarity theory is applied at a regional level to the religious and geopolitical tensions that exist between the IRI and KSA. Empirical data such as rhetorical devices and scriptural analysis indicates a link between state and religious legitimacy. Empirical content analysis is complemented by theoretical application, offering a unique link between global power distribution and regional power shifts across the region. Collectively, this paper combines theoretical pluralism and empiricism to explore how global powers inflect and constrain powers of regional players in the Middle East.

The article begins by contextualizing the religious incongruence that underpins modern hostility. The article then explores the way in which both Iran and Saudi Arabia's modern state legitimation is founded on reciprocal religious intolerance. The following section explains how nascent multipolarity affects the alliance structures of Saudi Arabia and Iran, and subsequently intensifies their antagonism, thus bifurcating their international relations. The final discussion section explores the competition dynamics between Iran and Saudi Arabia with respect to the Arab Springs.

\section{Contextualizing a Complex Contest}

7 he modern Middle East has been described by some as its own "Cold War"two regional major powers are pursuing strategic objectives through proxy contestation in the Middle East (Gauze 2014). The Middle East's circumstance is unique in multiple ways, one of which is the opaque influence of nonstate actors (NSAs). NSAs have vexed how states approach war in the twenty-first cen-

2 In describing Iran's religious political clout, King Abdullah II of Jordan coined the term "Shi'ite Crescent." 
tury due to their versatile ability to fill vacuums, complicate conflict zones, and act as proxies for states. This is particularly so in areas prone to sectarian tensions and the inflection of great power patrons. Both the KSA and IRI have modernized their twenty-first-century war strategies and instrumentalized violent NSAs for geostrategic goals. The confluence of modern tensions between the KSA and IRI can be traced back to Iran's Revolution in 1979 and linked to the Arab Uprisings beginning in late 2010. The KSA had just received F-15 fighter jets from the United States in addition to deeper liaison between Washington and Riyadh regarding Afghanistan's future (Hart 1998). Meanwhile, in Iran, Ayatollah Khomeini led the Revolution that ousted the secularist pro-U.S. Shah of Iran. Here, two key implications can be drawn from the 1979 Revolution: an inherent distrust toward the United States and a mutually irreconcilable distain between the KSA and Khomeini's post-Revolution IRI. Notably, Mabon suggests that after 1979, the contested Gulf security environment "transcended pure hard power competition, becoming a region embroiled in soft power competition" (Mabon 2016, 217). Ultimately, the ideological scope and intensity of Saudi-Iranian rivalry increased as a result of competing regional identities and global strategic alignments following the Iranian Revolution in 1979.

\section{Religious Incongruence}

Tomplex sectarianism drives the modern conflict between the KSA and IRI. Yet religious incongruence invariably predicates the deep-seated animosity. The Sunni-Shia split, which began over discrepancies regarding the mode of leadership succession within early Islam, soon intensified into a multiplex socio-political divergence, a political divergence that has endured centuries. Indeed, as Abdo notes, "Iran has never abandoned Ayatollah Ruhoollah Khomeini's vision of a pan-Islamic Middle East with Iran as its progenitor" (Abdo 2013, 51). The city of Karbala evokes innate reverence from Shia Muslims. This is because the Battle of Karbala and subsequent death of Imam Husayn bin 'Ali are central to modern Shia identity. ${ }^{3}$ Saud al Kabeer bin Abdul-Aziz bin Muhammad bin Saud added sectarian nuance to the Sunni-Shia divide when he led the Wahhabi sack of Karbala in 1802. Here, the nascent Saudi state led some 12,000 Wahhabi-inspired supporters to Karbala where they sacked the city indiscriminately killing thousands, while looting and destroying the Shrine of Imam Husayn. The Saudi sack of Karbala was economically conducive because the Shrine had an abundance of gold, jewels, and rare minerals (Rousseau 1809). Politically, the attack polarized the region and exacerbated sectarianism. Baghdad became a contested fault line between the Arabian Peninsula and greater Persia. The attack also broadly politicized religious adherence, fusing Wahhabi rhetoric with the House of Saud's legitimacy. Ultimately, modern sectarianism has developed out of religious divergence and its ideologically incongruous influence on state legitimation. While both Iran

3 The day of āshüra' commemorates the death of Husayn bin 'Ali on the tenth day of Muharram. 
and Saudi Arabia derive domestic legitimacy from religion, the respective interpretations are inherently incompatible. This incompatibility poses an intractable quandary for modern state legitimation.

\section{State Legitimation in Islamic Societies: A Weberian Analysis}

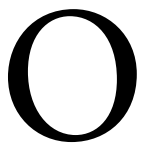

mnipresent in the structure of the state, religion is the central source of legitimation in both the KSA and IRI. German sociologist Max Weber divides the foundations of a state's legitimate authority into three categories: rational-legal, tradition, and charisma (Weber 1978). He also believed religion to be a crucial force in society. Most instructively, Weber's three determinants hinge largely on Islam in the case of both Saudi Arabia and Iran. Indeed, there are other, nonreligious forms of authority in Tehran and Riyadh. However, were religion precluded from either state's ethos, attaining Weberian legitimacy would prove foundationally problematic. What this means is that state authority hinges upon religious determinants (Wolin 1981). Islam's socio-political clout has permeated the judicial institutions, rendering Weber's "legal-rational" authority subordinate. "Tradition" as a mode of authority hinges on customary principles and finds root in patriarchal domination (Gerth and Mills 1958). Again, not uncommon to Islamic societies, customary principles often synergize with cultural Islam. Examples of this include Muslim tribal customs which predate Islam both in Saudi Arabia and Iran, and the way in which customary cultural traditions have synergized with Islam. "Charisma" as a precept of Weberian authority requires "virtue of which he is set apart from ordinary men and treated as endowed with supernatural, superhuman, or at least specifically exceptional powers or qualities" (Weber 1947, 297). Here, charismatic endearment is inextricably linked to Ayatollah Khomeini's meteoric rise. Emblematic of Ibn Saud's charismatic leadership, he was able to create the Ikhwan, a religious military brotherhood that aided Saud in consolidation of the Arabian Peninsula. Indeed, political reliance upon tribes was not uncommon in embryonically centralizing Islamic societies. Additionally, Saud brought Bedouin tribal allegiance under the Ikhwan. Thus, it is evident that the precepts of Weberian legitimacy are deeply embedded in Islamic legitimation within the political realm. What this means for the KSA and IRI is that authority hinges upon two interpretations of Islam that are in mutual, vehement rejection of each other. The institutionalization of religion both in Iran and Saudi Arabia solidified political legitimacy, but also mutual animosity.

\section{Statehood and Religion in the Arabian Peninsula}

Tlam is inextricably linked to the inception and predominance of the House of Saud. In 1744, a bay'ah, or "oath of loyalty," was established between the

Al Saud family and Muhammad ibn Abd al-Wahhab. This is widely consid- 
ered the inception of the first Saudi state (Metz 1992). Modern Saudi Arabia was founded on an alliance between Muhammad ibn Saud and Muhammad ibn Abd al-Wahhab, an influential theologian from Najd. What became the House of Saud, joined forces with a fundamentalist interpretation of Sunni Islam that became known as Wahhabism. Wahhabism is dogmatic in its interpretation of Islam, and unambiguous in its rejection of Shia Islam. The alliance was mutually beneficial, as Ibn Saud could unify the disparately restive Bedouin tribes through Wahhabism. Indeed, unification under the banner of Islam was often the only point of commonality between disparate tribes, but nonetheless an effective one, particularly against a common enemy. Saud was also able to consolidate his expansion into the Arabian Peninsula with religious justification afforded by al-Wahhab's support. In return, Ibn Saud ensured the propagation of Wahhabism and specific adherence to Tawhid in all conquered lands. The Tawhid was central to Al-Wahab's conception of Wahhabism and denotes the centrality of monotheism as expressed in the Shahada. It specifically pronounced, "There is no god but God and Muhammad is the messenger of God" (Ruthven 2004, 14). Al-Wahhab saw the value in political engagement declaring that, "without the coercive power of the state, religion is in danger, and without the discipline of revealed law, the state becomes a tyrannical organization" (Hopwood 1983, 23-25). The House of Saud did experience two interludes in opposition, briefly against the Ottoman Empire's viceroy of Egypt. However, its Wahhabi infusion endured, which Niblock notes is still "crucial to the nature of the Saudi state" (Niblock 1983, 11). The pervasiveness of Wahhabism served as a cultural conduit for tribal elites to consolidate authority through an application of social and legal Islam which "rests upon a belief in the sanctity of everyday routines" (Gerth and Mills 1958, 297). However, the nexus between Wahhabism and the Saudi state manifested in a way which institutionalized an interpretation of Islam that vehemently rejected Shia Islam as apostasy.

\section{The Iranian Resistance: The Islamic Revolution}

The 1979 Islamic Revolution ousted the Pahlavi dynasty of Iran. It had governed for over half a century. The Revolution institutionalized the endearing notion that a "Shiite Crescent" could manifest within the region. Internal factors such as corruption, budget imprudence, and tacit cultural assimilation rendered public perception disparate, but collectively indignant. Ruhollah Khomeini emerged as the first Supreme Leader of the nascent, reactionary Islamic state. Khomeini predicated his ascension on two central precepts: Wilayat al-Faqih' and a conceptually revisionist approach to the U.S.-led world order. The Wilayat al-Faq$i h$ ' translates to the "Guardian of the Islamic Jurist." It signifies central imperative of Twelver Islamic jurisprudence in guiding the IRI's judicial system. Regarding Khomeini's foreign stance, he unambiguously declared, "we have set as our goal the world-wide spread of the influence of Islam and the suppression of the rule of 
world conquerors.... We wish to cause the corrupt roots of Zionism, capitalism and communism to wither throughout the world" (Schirazi 1997, 8). Khomeini drew Weberian legitimation not only through religious "traditional-authority," but also through endearing "charisma" in his stokes to call on Islamic revolutions around the world. In this regard, Samuel Huntington drew legitimation parallels based on charisma between Khomeini and John Calvin (Huntington 1996, 111). Since the IRI's inception, Khomeini was an implacable enemy of the Saudi's Wahhabi regime. Most profoundly, Khomeini crystallized state Shi'ism in Iran and ensured the IRI remained the ideological vanguard of Shiites around the world. This religious clout has manifested around the Middle East and continues to cause angst in Sunni states cautious of an emergent "Shiite Crescent." Ultimately, the enduring dichotomy between the KSA and the IRI is twofold, and to a certain extent, bridges a religious and sectarian past with the geopolitical present.

\section{Multipolarity and the Power Transition Theory: A Structural Consideration}

7 he emergence of a multipolar world is the most profound structural change to the international system since the fall of the Soviet Union (Buzan 2011). L The unequivocal rise of China, Russian resurgence, and the U.S.' relative decline are all emblematic of a broad redistribution of power. Hence, multipolarity finds structural concordance with A.F.K. Organski's "Power Transition Theory" (PTT). ${ }^{4}$ The theory proves instructive in explaining how multipolarity manifests in the contest of the Gulf strategic environment. The PTT sees the international system as a hierarchical structure whereby a dominant power establishes a rulesbased "international order" (Organski 1958, 173). Here, states are classified in binary terms as either "satisfied" or "dissatisfied" within the international order. Within this paradigm, states are commensurately considered "status quo," or "revisionist" (see Figure 1).

The coalescence between the PTT and multipolarity finds root in Organski's nuanced stipulation concerning power. He notes: "power is relative, not absolute. It is not a characteristic of the nation itself but a characteristic of its relationship with other nations" (Organski 1958, 305). However, modernity and its precepts have both complicated and broadened the once military-centric calculus of power politics. Strategic bandwagoning is not anomalous to power politics. The pervasive and often omnipresent economic competition between modern powers commonly implicates multiple economic stakeholders. Consistent with the structural implications of multipolarity, Iran has fostered strategic regional alliances with states

4 There is still exuberant debate over whether a power transition will take place and by what means. See Cox, M. Power shift and the death of the west? Not yet! European Consortium for Political Research 10, no. 3 (2011): 416-24; Fenby, J. Will China dominate the $21^{\text {st }}$ century? Cambridge: Polity, 2014; Mearsheimer, J. China’s unpeaceful rise. Current History 105, no. 690 (April 2006): 160-62. 
such as Qatar, Turkey, Syria, and Iraq. Hence, a structural change in polarity has invariable regional implications. For the KSA and IRI, international alliance structures are divergent. While the KSA supports a waning U.S.-led world order, the IRI is forming strategic alliances with great powers like China and Russia. Indeed, ambitious powers are cognizant of this power shift as Geranmayeh and Liik note: "Iran and Russia share an aspiration to create and maintain a 'multipolar' world order that would treat both of them as important decision-makers" (Nizameddin $2008,475-500)$. Not only does this add dynamism to the ostensibly rigid realist PTT, it coalesces with the nascence of multipolarity. For the KSA and IRI, this denotes a two-pronged quandary whereby the flux international system exacerbates pre-existing sectarian tensions.

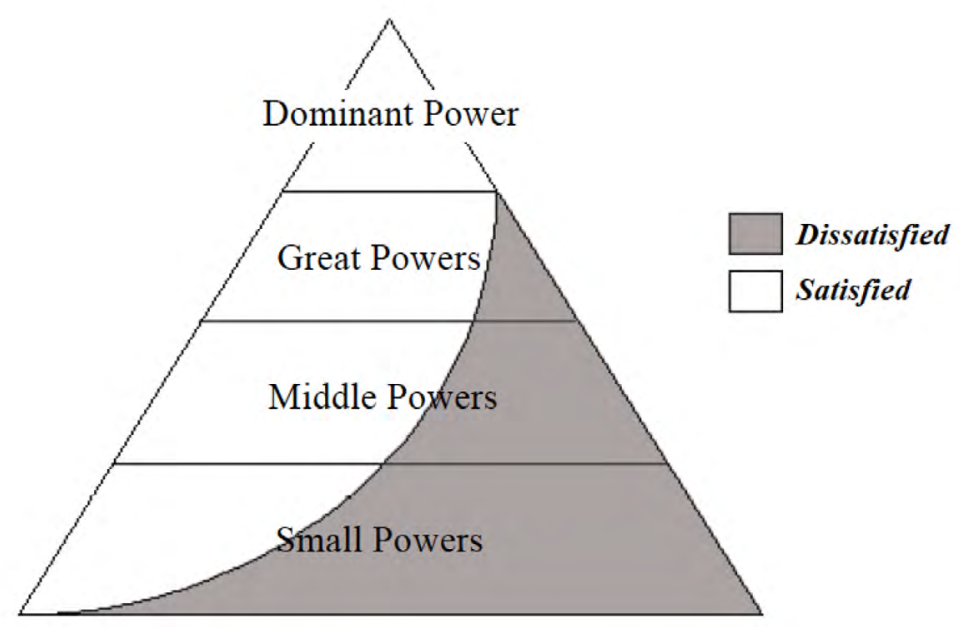

Figure 1: Global Power Hierarchy. The dominant power is seen as the pre-eminent international power rather than hegemon. Source: Kugler, J. (2006, December 11). Power and power hierarchies in the global and regional context. GIGA German Institute of Global and Area Studies, Hamburg.

\section{Saudi-Iranian Manifestations: Foreign Fault Lines-United States and Israel}

7 he most intractable feature of modern animosity between the IRI and the KSA is the latter's longstanding strategic alliance with the United States, and the former's perpetual disdain for perceived U.S. imperialism. This animosity is broadly exacerbated by the politics of oil, thus evidencing the centrality of economic and strategic clout. Upon the discovery of vast and easily extractable oil reserves in the KSA, the United States began to foster a strategic relationship that would see the KSA integrate within the emergent U.S.-led world order. Indeed, the discovery of oil proved timely and served as a conduit to sway the state 
from autochthonous tribalism to a more centralized and governable modern one. Indeed as Haykel explains, "Oil magnified the clientelist power of the Saudi rulers to unprecedented levels at a time when the modern centralizing state was also becoming the dominant institution in society. This then stripped many hitherto active agents in society, such as tribal shaykhs" (Haykel 2015, 128). Thus, while an association with al-Wahhab religiously legitimized the first Saudi State, an association with the United States proved broadly conducive to Saudi Arabia's strategic interests. As Jones notes, Saudi Arabia's oil wealth is "passed along in myriad social welfare programs that include free education, free healthcare, sweeping employment support, subsidies for industry and business, and even the provision of copious amounts of water" (Jones 2011, 47).

Contrasting the Saudi experience, the United States has never truly experienced a productive relationship with the IRI. This is largely due to the anti-American and anti-Zionist rhetoric that gave rise to Khomeini's rise (Nasr 2016, 125). Hence, Weberian legitimacy hinges on such foundational ideals. These include Iran's deep-seated aversion and suspicion to colonial and imperial overtures. The IRI's modern divergence with the KSA finds root in its rejection of the U.S.-led world order and Zionism. In a 2015 meeting, Ayatollah Khamenei told Russian President Vladimir Putin that the "long-term plan of the US is against the interests of all nations, particularly our two nations, which can be thwarted by closer cooperation" (Geranmayeh and Liik 2016, 2). What this denotes is a three-pronged dissension between the KSA and IRI, those being: religiously incongruent sources of political legitimacy, conflicting regional objectives, and divergent international alliances. This antipathy is a point of commonality with many disenfranchised Muslims around the world and Arabs in the region which has proved endearing to Iran in uniting Muslims in opposition to the United States and Israel. Rostami-Povey $(2010,6)$ explains how this contemporary aversion works to mitigate historical and cultural incongruence:

the ordinary people tend to communicate with each other through a mutual perception of the roles of Israel and the USA in the region. Iran is popular simply because it is the only country in the region that supports the Palestinians and the Lebanese while opposing Zionism and the Western-in particular US-policies in the region.

The 2006 Lebanese War crystallized an already prolific history of animosity between the IRI and KSA. Through its support of Hezbollah and Hamas, Iran has been actively, and consistently involved in hostility toward Israel. Its anti-Zionist rhetoric is harmonious with its rejection of the U.S.-led order and reactionary appeal to the Islamic revolution. Thus, while Ibn Saud's consolidation of modern Arabia was largely contingent upon support from the West, Khomeini's consoli- 
dation of the Islamic Republic was founded on fundamental antipathy toward the West. The IRI's fundamental aversion to the U.S.-led order makes Tehran a generative client to competing great powers such as Russia, thus linking its regional standing to its strategic ambitions and global alignments.

\section{The New Middle East Cold War: The Multiple Hierarchy Model}

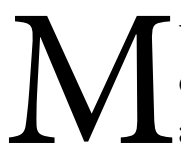

ultipolarity offers regional opportunity for the KSA and IRI. This is because both states have the capacity to wield influence commensurate of a regional hegemon. As Peter Harris explains, "the same principles that hold at the global level define interactions within regional hierarchies" (Harris 2014, 241-59). Here, great power alliance structures bifurcate the IRI and the KSA. As the fluid KSA maintains its support of the status quo despite the uncertainty of U.S. global leadership or regional arbitration, the IRI has enhanced its geostrategic alignment with likeminded revisionist states internationally in the geostrategic case of Russia, but also through pragmatic economic opportunism with China. From this, regional shifts in power have resulted. Thus, the PTT highlights how structural changes in polarity affect regional dynamics (Organski 1958). Here, the KSA benefit from the status quo rules-based order. In contrast, as a "revisionist state," the IRI does not benefit from the status quo and consequently seeks to disrupt and ultimately reorder it. The PTT becomes ever more applicable as U.S. leadership in the Middle East becomes more tepid. Tepidity in leadership through Washington's political maneuver in moving the U.S. Embassy from Tel Aviv to Jerusalem in December 2017, but also tepidity through the dwindling but once omnipresent force presented by the United States. Now, spheres of regional influence appear more salient, while spheres of broader geopolitical clout have manifested symptomatically of a broader shift in polarity. The precepts of multipolarity denote a refocus on regional spheres of influence, while the PTT observes the way in which the international system shifts commensurate to tectonically structural alternations in polarity and power parity. It is within this context that the KSA and IRI's ideological incongruence has seen augmented bifurcation as a result of polarity shifts, resulting in protracted modern animosity.

\section{Lemke's PTT and (Parity) Proxy Wars: The Multiple Hierarchy Model}

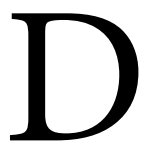

ouglas Lemke offers nuance to the PTT by postulating that regional subsystems exist subsidiary to the international system, compromising of the global system (Lemke 1995). It is through Lemke's adaptation that the PTT best explains Saudi-Iranian competition. Figure 2 observes the interaction between international and regional hierarchies. Lemke notes, "When a dissatisfied 
member of a given local hierarchy achieves parity with the local dominant power it has the opportunity to go to war to alter the local status quo" (Lemke 1995, 149). It is difficult to ascribe dominance to a single state in the Middle East due to the complex asymmetry in power between states such as Iran and Israel. Here, Iran is more powerful than Israel on measurements such as population, economic productivity, etc. However, Israel possesses opaque nuclear capabilities and a security guarantee from the United States. However, the manifestation of dissatisfaction plays out through sectarian competition within the region. The way in which states pursue their interests are multifaceted and often include instances of hard and soft power. Given the enlarged role Islam plays in Middle Eastern society, religion manifests as an instrument of clout. Regional influence has become paramount due to declining U.S. presence in the region, and the nascent, systematic restructuring of polarity in the international system. Furthermore, Lemke $(1995,149)$ notes that "most of the time the local dominant country enjoys preponderance of power over its neighbors in the local hierarchy, and as a result there is peace." This is problematic for the Middle East region because it implies that an absence of local dominance denotes instability. Here, the PTT highlights the volatile nature of the Middle East, but also illuminates the nature of modern "revisionist" and "status quo" proxy-war competition.

The International Power Cone

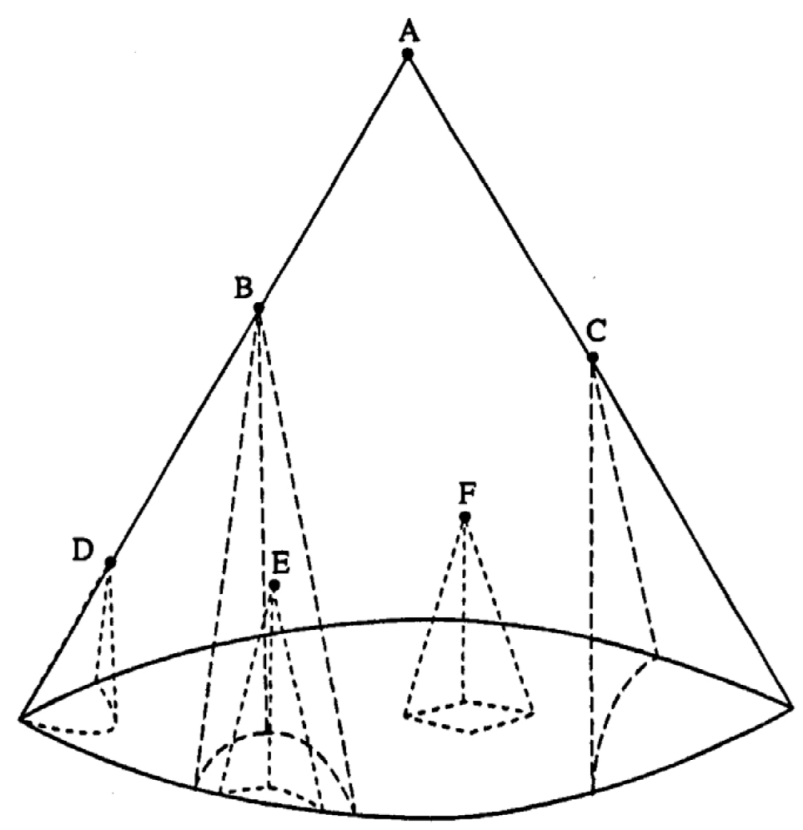

Figure 2. Lemke’s “International Power Cone." Source: Lemke, D. (1995). Toward a general understanding of parity and war. Conflict Management and Peace Science, 14(2), 145. 


\section{Regional Manifestations}

7 he KSA and IRI have not engaged in the war envisioned by Organski's original PTT, nor Lemke's nuanced adaptation. This is symptomatic of an anomalous phenomenon: globalized multipolarity. Here, both the absolute cost of war and the interconnectedness of the Middle East region rationally dissuade Tehran and Riyadh from direct confrontation. Instead, stoking revolutionary uprisings or supporting counterrevolutionary efforts, in addition to the financing of proxy wars, have proven both economically prudent and politically shrewd means of expressing dissatisfaction with the regional status quo. While Iraq highlights Lemke's stipulation regarding great power inflection on regional hierarchies, Yemen typifies the sectarian complexities complicating the strategic rivalry. With regard to polarity theory, the Iraq case highlights Washington's hegemonic unipolar overreach. Conversely, multipolarity denotes an increased emphasis on regionalism, explaining the intensification in proxy warfare, sectarianism, and uprising. Indeed, the empirical majority of Middle Eastern conflicts find predication on religious incongruence. However, polarity theory offers new insights into the constraints and explanations of contemporaneous geopolitical manifestations.

The unprecedented interconnectedness afforded through globalization evidences the broad geostrategic necessity and its salient precedence over the ubiquitously rationalized religious justification. Though religious discordance underpins the rhetoric of such sectarianism, the clouded proliferation of loosely associated, and poorly structured religious-militias negates the need for direct warfare. In its place, however, manifests an opaque consortium of nonstate actor groups of varying degrees of political legitimacy and international recognition. Such groups often engage in fleeting alliances of pragmatic mutual gain, seldom espousing shared religious ideals and rarely shared political objectives. Power parity is the most crucial variable in the PTT; this is because it postulates the probability of war. The opaque and complex asymmetry of the Middle East's hierarchy obfuscates a state's ability to aptly discern power parity in the region. Hence, tacit regional competition manifests in two ways: proxy warfare and in the case of the IRI, encouraging subversive revolutions. In light of increased regionalism, the Arab Springs offered the ideal catalyst for influencing contestation through proxy warfare.

\section{Arab Springs}

7 he complexities and breadth of political outcomes from the Arab Spring vary in such diversity that generalized summation would be simplistically erroneous, though one particular observation may be made from the "springs" that occurred across the Middle East. That is, a geographic uprising of divergent causes and stressors, all symptomatic of a restive region no longer beholden, afraid, or perturbed by the repercussions of great powers outside proximi- 
ty of geographic concern. The competition between the KSA and the IRI has been characterized by some as a "New Middle East Cold War" (Gause 2014). Gause (2014) believes this is because socioreligious ideology and political affinity supersede pure military might in such regional competition. Indeed, Ismail (2016) affirms this view by observing a causal relation between Saudi clerics' pronouncements and their political undertones. However, it is nascent multipolarity which facilitates such inter-regional cold-war strategic overtures. Indeed, modern globalization necessitates and ultimately ensures the implicit "cold" nature of such rivalry. The Arab Springs also created a sectarian Gulf. During the Bahraini Spring of 2011, the Saudi-led intervention proved instrumental in quelling an anti-government uprising and supporting the Sunni minority government. While the KSA looked to support pre-existing (status quo) regimes such as those in Egypt, Tunisia, and Bahrain, the IRI contrastingly perpetuated its Islamic revolutionary zeal. Highlighting the bifurcated alignment within and out status quo status, Mabon notes the Arab Springs served to "isolate Iran and mobilize Sunnis across the region against Iran and the Assad regime in Syria" (Matthiesen 2013, 111).

Although from the outset, some IRI and KSA's policy toward the Arab Springs were more opaque than ostensibly portrayed. This was done so as to maintain harmony between the states' endgame objectives, while maintaining strategic ambiguity so as to maintain influential versatility throughout the uncertainty of the uprisings.

\section{Iraq}

The U.S. invasion of Iraq and subsequent chaos that ensued is indicative of the concomitant nature of PTT local hierarchies within the broader international hierarchy. This is because the U.S.'s most climacteric act, at its hierarchical dominance precipitated what would become Iran's regional reassertion and window for revisionism. For this reason, Iraq serves not only as a historic fault line between Shiite Iran and the nascent Wahhabi Saudi state, but also as the catalyst for the modern power vacuum presented subsequent of U.S. withdrawal in the twenty-first century. As Lemke $(1995,149)$ explains, "Local hierarchies really are local; they comprise proximate states that are able to move enough of their resources into each other's territory to make warfare possible." Here, Iraq serves as Iran's bridging of the religious past with the geopolitical present, serving as a conduit between the regional hierarchy and global order. It is intrinsically linked to the IRI and KSA both geographically and socioethnically. When discussing the relationship between the dominant state and local dominant country, Lemke $(1995,238)$ notes that "the status quo of the local hierarchy therefore might well be created, defended, or simply affected by more powerful external actors." This is particularly applicable to Iraq because the U.S.'s intervention weakened its international standing as the world's sole superpower. For instance, in Figure 2, one might il- 
lustrate the U.S.s intervention in Iraq as $A$ reflecting Washington, inflecting an imagined regional hierarchy whereby $E$ representing Iraq, affecting the relative power of Iran, representing C. Hence, U.S. overreach concurrently reordered the Middle Eastern subsystem by providing a vacuum for Iranian influence following the fall of Ba'athist Iraq. Ultimately, the same sacred fault line which bifurcated political Islam centuries ago remains commensurately relevant to geopolitics. While U.S. overreach is explained by the PTT's assumptions, the regional implications of Washington's overreach indicate a link between global power distribution and the constraints of regional power dynamics.

\section{Yemen}

Beginning in 2015, the Yemeni Civil War typifies the opaque nature of opportunism and antagonistic competition between the KSA and IRI. Both the nature and proximity of proxy warfare permit a certain degree of ambiguity through militias. Here, just as ideological clout transcends the geographic parameters of Organski's PTT, ostensibly independent militias with affinities to the ideologies espoused by Riyadh and Tehran obfuscate the groups' true objectives. Neighboring the KSA and occupying the Arabian Peninsula, Yemen is geopolitically central to the KSA's regional standing. However, Yemen's historically established Shia Zaidi sect complicates the modern state's social fabric and offers Tehran the ideological space to seek geopolitical influence within these communities. What began in 2011 as an internal presidential succession row, soon descended into a multidimensional conflict at the heart of the Saudi-Iranian proxy war. In response to the predominantly Shia-led Zaidi "Houthi" rebel movement capturing Yemen's capital Sana'a, the KSA led a military intervention to remove the rebels and reinstall ousted president Abdrabbuh Mansur Hadi. Suspicious of the looming yet opaque "Shiite Crescent," the KSA accused the IRI of supporting the Houthis as part of the broader regional competition, an accusation that has been corroborated by the United Nations (UN) (Landry 2015). Despite being the poorest Arab nation, Yemen has seen some of the worst bloodshed in history with some 10,000 civilians killed and 40,000 injured (al-Haj 2017). The impoverished nation is of geostrategic importance to both Tehran and Riyadh as it shares a border with the KSA and is split demographically with close to half its population of the Shia faith. The geostrategic imperative of regional primacy in Yemen is exemplified by the Houthi's assassination of the former president Ali Abdullah Saleh in December 2017. Saleh and his forces had been strategically aligned with the Houthis against exiled President Hadi. However, Saleh's public declaration of willingness to cooperate with Riyadh in the cessation of hostilities and peace negotiations was ultimately incongruent with Tehran's regional grand strategy. For many, Saleh was a symbol of unity in Yemen. His death invariably places Yemen deeper in the midst of a proxy war between two external powers with little hope or intention of resolution imminent. 


\section{Conclusions}

$\mathrm{R}$ eligious incongruence underpins historical Saudi-Iranian animosity. This incongruence forms just one piece of a complex puzzle. Modern determinants such as sectarianism, war, and mistrust have predicated its enduring nature. Though state formation, ethnocentrism, and draconian methods of legitimation equally compound the complex aversions espoused in Tehran and Riyadh. Geopolitical theories are useful tools of analysis because they provide a structural foundation to illuminate multifaceted conflicts. Multipolarity and the implications of the PTT are invariably central determinants of conflicts in an age of such complex interdependence in international relations. As explored throughout this article, the complex rivalry between Riyadh and Tehran is best understood within the contemporaneous context of global polarity and these states' commensurate relations to the great powers discussed.

Ultimately, the findings of this paper indicate that the oscillating nature of the international system continues to protract or pacify the nature of state-to-state relations at a regional level. Dual layered hierarchical measurements, in tandem with empirical contextualization, fill a theoretical gap in the ideological and geopolitical power dynamic between Iran and Saudi Arabia. Within the spatial and longitudinal scope of this paper, the findings affirm Lemke's stipulation that great power inflection affects regional power structures as illustrated in the "International Power Cone." Ultimately, the paper finds that shifts in great power distribution affect constraints on regional power dynamics as explored through the enduring strategic rivalry between Saudi Arabia and IRI.

\section{References}

Abdo, G. 2013. "The New Sectarianism: The Arab Uprisings and the Rebirth of the Shi'a-Sunni Divide." Brookings Institution, Analysis Paper, 29.

Buzan, B. 2011. “A World Order Without Superpowers: Decentred Globalism.” International Relations 25 (5): 2-25.

Cox, M. 2011. "Power Shift and the Death of the West? Not Yet!" European Consortium for Political Research 10 (3): 416-24.

Fenby, J. 2014. Will China Dominate the $21^{\text {st }}$ Century? Cambridge: Polity.

Gause, F. G. III. 2014. "Beyond Sectarianism: The New Middle East Cold War.” Brookings Doha Center Analysis Paper, 11. 
Geranmayeh, E., and K. Liik. 2016."The New Power Couple: Russia and Iran in the Middle East.” European Council on Foreign Relations 186 (September): 1-16.

Gerth, H., and C. W. Mills. 1958. "From Max Weber: Essays in." Sociology 110: 129-156.

Harris, P. 2014. "Problems with Power-Transition Theory: Beyond the Vanishing Disparities Thesis." Asian Security 10 (3): 241-59.

Hart, P. 1998. Saudi Arabia and the United States: Birth of a Security Partnership. Indiana: Indiana University Press.

Haykel, B. 2015. Saudi Arabia in Transition: Insights on Social, Political, Economic and Religious Change. Cambridge: Cambridge University Press.

Hopwood, D. 1983. “The Ideological Basis: Ibn Abd al-Wahhab's Muslim Revivalism." In State Society and Economy in Saudi Arabia, edited by Tim Niblock, 23-25. London: Croom Helm.

Huntington, S. 1996. Clash of Civilizations and the Remaking of World Order. New Delhi: Penguin Books.

Ismail, R. 2016. Saudi Clerics and Shia Islam. Oxford: Oxford University Press.

Jones, T. 2011. "Saudi Arabia versus the Arab Spring." Raritan 31 (2): 43-59.

Kausch, K. 2015 "Competitive Multipolarity in the Middle East." Italian Journal of International Affairs 50 (3): 1-15.

Lemke, D. 1995. “Toward a General Understanding of Parity and War." Conflict Management and Peace Science 14 (2): 143-62.

Mabon, S. 2016. Saudi Arabia and Iran: Power and Rivalry in the Middle East. London: I.B. Tauris.

Matthiesen, T. 2013. Sectarian Gulf: Bahrain, Saudi Arabia, and the Arab Spring that Wasn't. Stanford: Stanford University Press.

Mearsheimer, J. 2006. “China’s Unpeaceful Rise.” Current History 105, no. 690 (April): 160-62.

Metz, H. 1992. Saudi Arabia: A Country Study. Washington, DC: Library of Congress. 
Nasr, V. 2016. The Shia Revival: How Conflicts Within Islam Will Shape the Future. New York: W.W. Norton.

Niblock, T. 1983. State Society and Economy in Saudi Arabia. London: Croom Helm.

Nizameddin, T. 2008. "Squaring the Middle East Triangle in Lebanon: Russia and the Iran-Syria-Hezbollah Nexus." The Slavonic and East European Review 86, no. 3 (July): 475-500.

Rostami-Povey, E. 2010. Iran's Influence. New York: Zed Books.

Rousseau, J. B. 1809. Description du Pachalik du Baghdad Suivie d'une Notice Historique sur les Wahabis. Paris: Treuttel and Würtz.

Ruthven, M. 2004. Historical Atlas of Islam. Cambridge: Harvard University Press.

Schirazi, A. 1997. The Constitution of Iran: Politics and the State in the Islamic Republic. New York: Tauris.

Weber, M. 1947. Theory of Social and Economic Organization, Translated by A. Henderson, and T. Parsons. Glencoe: Free Press Falcon's Wing Press.

Wolin, S. 1981. "Max Weber: Legitimation, Method, and the Politics of Theory." Political Theory 9 (3): 401-24. 